\title{
Spatio-temporal variability in prey harvest and reproductive ecology of a piscivorous seabird, Cerorhinca monocerata, in an upwelling system
}

\author{
J. A. Thayer ${ }^{1,2, *}$, W. J. Sydeman ${ }^{2}$ \\ ${ }^{1}$ Marine Ecology Division, PRBO Conservation Science, 4990 Shoreline Highway, Stinson Beach, California 94970, USA \\ ${ }^{2}$ Wildlife, Fish and Conservation Biology, University of California, One Shields Ave., Davis, California 95616, USA
}

\begin{abstract}
Ocean climate affects the life history and demography of top marine predators through changes in local prey availability. In the California Current System, abundance and distribution of mid trophic-level forage fish may be affected by seasonal and interannual variability in upwelling. We tested the hypothesis that upwelling influences forage fish availability and response of a seabird, but that the effects differ spatially within a region. We examined the availability of multiple forage species and the reproductive ecology of rhinoceros auklets Cerorhinca monocerata relative to ocean climate over 11 yr (1993 to 2003) for 2 colonies off central California: one near the shelf break and another at the coastline. The upwelling index that we used increased through time, while sea surface temperature (SST) generally decreased. Abundance indices of juvenile rockfish Sebastes spp. fluctuated, while northern anchovy Engraulis mordax decreased. Diet of the auklet reflected availability of prey in the environment. Auklet reproduction was affected by both marine climate and prey availability. Seabird breeding as well as harvest of anchovy, rockfish and Pacific saury Cololabis saira were linked to offspring growth, but growth was not necessarily related to offspring survival. Offspring survival was inversely correlated with SST and positively correlated with mass of prey rather than diet composition. Auklet reproduction was more variable offshore than inshore, possibly reflecting variation in the upwelling cells affecting prey availability within the foraging range of birds from each colony.
\end{abstract}

KEY WORDS: Rhinoceros auklet $\cdot$ Northern anchovy $\cdot$ Juvenile rockfish $\cdot$ Pacific saury $\cdot$ Sea surface temperature · Upwelling · Offspring survival · Growth · Timing of breeding · Prey switching

\section{INTRODUCTION}

Temporal variation in ocean climate affects demographic processes of marine birds indirectly through changes in prey availability (Croxall et al. 2002). Environmental variation has been shown to affect zooplankton, forage fish and squid, which form the basis of food webs supporting seabirds and other top predators (Brodeur \& Pearcy 1992, MacFarlane \& Beamish 1992, Chavez et al. 2002, Field et al. in press). Integrating predator responses with prey and climate, however, is difficult. Attempts to understand biophysical links have revealed that seabird breeding phenology is sensitive to climate variability (Bertram et al. 2001,
Abraham \& Sydeman 2004, Frederiksen et al. 2004). Effects of diet on seabird demographic processes such as reproductive performance have been widely demonstrated, but the direct influence of prey availability has been difficult to establish due to lack of independent measures of food resources in the environment (but see Monaghan et al. 1996, Kitaysky et al. 2000, Abraham \& Sydeman 2004). Where independent measures are available, some relationships have been found in relatively simple systems (e.g. Barents Sea; Barrett 2002). Often, however, interpretations are confounded by non-linear responses (Cury \& Roy 1989, Mills et al. in press) or effects of multiple variables (Suryan et al. 2002, Abraham \& Sydeman 2004). 
Effects of climate variability on marine organisms vary spatially as well as temporally (Brodeur et al. 1996, Mueter et al. 2002, Inchausti et al. 2003). Few comparative studies of the same species in different environments exist. In at least one study, seabird productivity and diet differed between breeding sites, but relationships between reproductive ecology and the oceanic environment were not clear (Decker et al. 1995). Another study, however, revealed different effects of sea surface temperature (SST) anomalies on similar seabird species breeding in the same location but with different foraging habitats (Inchausti et al. 2003). More comparisons are needed to understand spatial and temporal differences in biological responses to environmental variability.

The California Current System (CCS) is an eastern boundary current system where hydrography is driven by a complex mixture of geostrophic and winddriven flow patterns (Chavez et al. 2002, Collins et al. 2003). Northwest winds force coastal upwelling, particularly near capes and headlands. Upwelling is strongest during the spring and summer and leads to nutrient enrichment and cool SST, but mixed layer depth can modify this relationship (McGowen et al. 2003). The effect of upwelling is altered during El Niño Southern Oscillation (ENSO) events when the mixed layer deepens, leading to warm SST and poor nutrient input into the photic zone, even when upwelling is active. In contrast, La Niña events are characterized by strengthened winds and unusually cold ocean temperatures. Although primary and secondary production is positively correlated with upwelling, responses may be nonlinear due to increased advection of organisms offshore or to turbulence that disrupts food web development (Cury \& Roy 1989, Wroblewski et al. 1989).

We examined the response of 2 colonies of breeding rhinoceros auklets Cerorhinca monocerata to fluctuations in upwelling, SST and forage fish availability over 11 yr in the central CCS (see Fig. 1). Specifically, our objectives were to (1) examine temporal patterns in upwelling and SST, prey availability and reproductive ecology between 1993 and 2003; (2) examine patterns of spatial variability (inshore vs. offshore) in SST and auklet ecology and (3) investigate and evaluate spatiotemporal coupling relative to basin-scale phenomena such as ENSO, and predator-prey responses.

\section{MATERIALS AND METHODS}

Study sites. Southeast Farallon Island (SFI) $\left(37^{\circ} 42^{\prime} \mathrm{N}, 123^{\circ} 00^{\prime} \mathrm{W}\right)$, the largest seabird community in the continental USA, is located $29 \mathrm{~km}$ south of Pt. Reyes, California and $8 \mathrm{~km}$ east of the continental

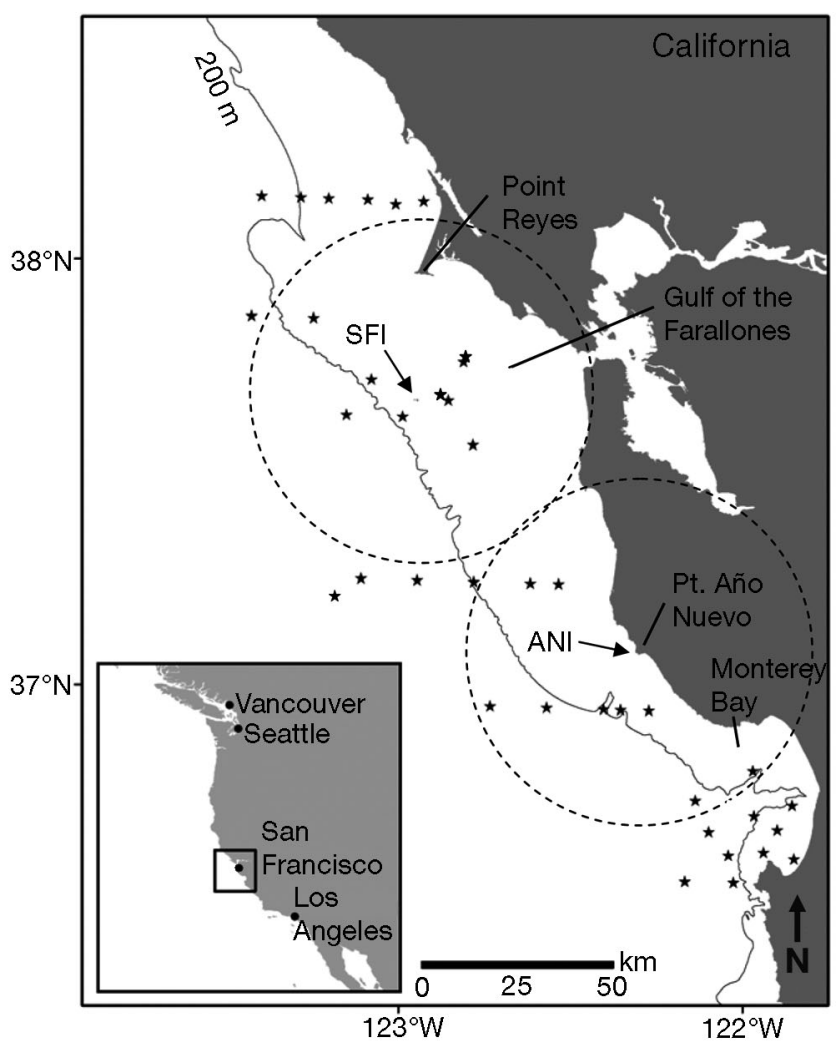

Fig. 1. Study area in the central California Current System. A $50 \mathrm{~km}$ radius is shown around each colony. ( $\star$ ) NMFS trawl stations; SFI: Southeast Farallon Island; ANI: Año Nuevo Island

shelf break. Cool, salty, upwelled, water near Pt. Reyes is recirculated south of the point and may envelope SFI (Steger et al. 2000). Año Nuevo Island (ANI) $\left(37^{\circ} 06^{\prime} \mathrm{N}, 122^{\circ} 20^{\prime} \mathrm{W}\right)$ is $90 \mathrm{~km}$ south of SFI. ANI is $1 \mathrm{~km}$ west of Pt. Año Nuevo and $11 \mathrm{~km}$ northeast of submarine canyons extending inward from the shelf break. The Pt. Año Nuevo upwelling cell is the source of cold, salty water that flows south across northern Monterey Bay (Collins et al. 2003) and may also become entrained in a persistent eddy offshore (Baltz 1997).

Physical oceanography. To index temporal variability in upwelling, we averaged daily Bakun upwelling indices (UI) at $36^{\circ} \mathrm{N}$ and $39^{\circ} \mathrm{N}$ over 2-mo periods from winter through summer each year (from December to January, February-March, April-May, June-July; www.pfeg.noaa.gov/products/PFEL). These indices reflect alongshore transport of water $\left(\mathrm{m}^{3} \mathrm{~s}^{-1} 100 \mathrm{~m}^{-1}\right.$ of coastline) due to wind stress calculated from synoptic atmospheric pressure data. We used anomaly statistics to graphically depict the UI (bimonthly value: longterm 1967 to 2003 climatology). UI values were the same for both SFI and ANI due to the large-scale pressure fields used to derive these bimonthly indices. 
Since UI is a relatively coarse index of regional oceanographic conditions, we used SST to distinguish local ocean differences between the colonies. SST is the result of upwelling and thermocline depth. We derived bimonthly SST from Advanced Very High Resolution Radiometer (AVHRR) satellite data (http:// oceanesip.jpl.nasa./gov) for a $50 \mathrm{~km}$ radius around each colony, which encompasses the probable auklet foraging range (McFarlane-Tranquilla et al. 2004). Although AVHRR-derived SST can be biased by insolation, this measure was correlated with in situ SST at SFI at $1 \mathrm{~m}$ depth (1986 to 2003: $\mathrm{R}^{2}{ }_{\text {Dec-Jan }}=0.95$; $\mathrm{R}_{\text {Feb-Mar }}^{2}=0.92 ; \mathrm{R}_{\text {Apr-May }}^{2}=0.82 ; \mathrm{R}_{\text {Jun-Jul }}^{2}=0.75$ ). Satellite-derived SST also correlates with SST measured by coastal buoys (Armstrong 2000). We created AVHRRderived SST anomalies by subtracting the long-term mean in situ SST (1955 to 2003) from satellite bimonthly SST values. We acknowledge differences between these 2 measurements, but used anomalies for illustrative purposes, recognizing that the satellite and in situ SST were closely correlated.

Prey availability. Forage fish abundance was estimated from surveys of the National Marine Fisheries Service (NMFS) and California Cooperative Oceanic Fisheries Investigations (CalCOFI). NMFS conducts midwater trawls for juvenile rockfish from May to June each year (Fig. 1). Methodology is available in Ralston \& Howard (1995), Field et al. (in press) and Mills et al. (in press). Briefly, NMFS derived a juvenile rockfish abundance index by fitting trawl data, normalized to 100 d-old fish, to a delta-GLM (Generalised Linear Model) incorporating year, sampling station and calendar date effects with no interactions (J. Field pers. comm.). We have used this annual index for analyses in the present study. This index differs from that used by us in previous predator-prey analyses (Mills et al. in press).

Since 1951, CalCOFI icthyoplankton surveys including anchovy have been conducted quarterly off southern California between 31 and $35^{\circ} \mathrm{N}$ latitude (CalCOFI lines 77 to 93 ; Smith \& Moser 2003). Although this is south of our sampling area, the central subpopulation of northern anchovy extends approximately from Punta Baja, Baja California, north to San Francisco (Mais 1990). As no index of anchovy abundance is available, we developed one. We used the geometric mean of anchovy (catch +1$)$ in the April net samples from all sampling stations shoreward of the core of the California Current Jet, a dynamic boundary identified from sea height each year ( $\mathrm{S}$. Bograd pers. comm.; see Yen et al. in press). We used the jet as the westernmost limit of sampling stations, because anchovy rarely occupy habitat beyond this boundary (Brewer \& Smith 1982, Mais 1990).

Seabird reproductive ecology. In central California, rhinoceros auklets recolonized SFI in 1972 after an absence of almost a century (Ainley \& Lewis 1974), while the colony at ANI was established in approximately 1982 (LeValley \& Evens 1982). There are roughly 1500 rhinoceros auklets in the SFI population. With active management, i.e. habitat protection and nest boxes, the ANI population grew to 270 individuals by 2003 . We studied breeding ecology over 11 yr (1993 to 2003) at these colonies. These populations are linked by dispersal (authors' unpubl. data). We studied reproductive parameters in both natural burrows and nest boxes. Nest boxes were constructed using $13 \mathrm{~mm}$ plywood $(61 \times 25 \times 25 \mathrm{~cm})$ with $15 \mathrm{~cm}$ diameter polystyrene entrance tunnels. Tunnels were 60 to $120 \mathrm{~cm}$ long, randomly selected to mimic natural burrow variation. Nests were checked every 5 to $7 \mathrm{~d}$, either manually (boxes) or using an infrared burrow camera. Once an egg was laid, the nest was left undisturbed until hatching was expected. Hatching success did not vary significantly between colonies or years (1995 to 2003: mean $0.77 \pm 0.02(\mathrm{SE}), \mathrm{n}=1094$; logistic regression $\mathrm{LRS}_{8(\mathrm{yr})}=15.72, \mathrm{p}=0.073 ; \mathrm{LRS}_{1 \text { (colony) }}=0.19, \mathrm{p}=0.665$ ). Therefore, we focused on the more variable period after hatching. We used hatching date as our proxy for timing of breeding. Growth was determined by weighing offspring $( \pm 5 \mathrm{~g}$ ) every 5 to $7 \mathrm{~d}$ until fledging. Offspring growth was linear between 14 to $35 \mathrm{~d}$. To calculate annual growth rates $\left(\mathrm{g} \mathrm{d}^{-1}\right)$, weight on Day 14 or 15 was subtracted from weight on Day 35. We divided the result by 21 or $20 \mathrm{~d}$, respectively $\left(\mathrm{n}_{\mathrm{SFI}}=123 ; \mathrm{n}_{\mathrm{ANI}}=\right.$ 217). We defined offspring survival as the ratio of chicks fledged to chicks hatched. Over time, pairs in nest boxes demonstrated similar productivity to pairs in natural burrows. Young, inexperienced birds often first occupy boxes, and as birds age, reproductive performance increases (Forslund \& Part 1995). Inexperienced breeders, i.e. unbanded individuals that occupied new boxes, tended to breed later and fail at the incubation stage. Age or experience, therefore, affected hatching success, but did not affect our focal parameters, i.e. timing of hatch and offspring diet, growth and survival.

Diet of this piscivorous, diving seabird was sampled approximately weekly from June to July each year by capturing adults as they returned at dusk to provision their young. We assumed that individual chicks monitored for growth and survival were fed similar prey to that established by this 'population-level' diet sampling. When delivering food to offspring, parents carry multiple prey items crosswise in their bills, termed a 'bill load'. As multiple prey from 1 bill load are not statistically independent, we summarized diet composition (\% by mass) in terms of the 'bill load' as the sampling unit. Occasionally we obtained partial fish in bill loads. Since intact fish were usually brought to offspring, we estimated mass for partial fishes by approximating fork length when possible in length-weight 
relationships. We also calculated mean bill load mass in each year, using only complete bill loads $\left(\mathrm{n}_{\mathrm{SFI}}=478\right.$; $\left.\mathrm{n}_{\mathrm{ANI}}=196\right)$.

Statistical analyses. Oceanographic conditions in the months prior to breeding may influence seabird breeding ecology. Since the birds begin breeding about April, we used 2-mo means of SST from December to May for correlations with timing of breeding. Spawning or parturition (larval release) for anchovy and rockfish in the CCS occurs largely between December to June each year (Mais 1990, Love et al. 2002). Since auklet diet sampling occurred from June to July, we examined UI and SST during that period and also lagged 2-mo means from December to May. Spawning has been recorded in all months for saury (Hughes 1973), so we did not expect strong linkages of saury take with local ocean conditions.

To test for spatial and temporal variation in diet and/or life history parameters, we used either ANCOVA (for continuous variables) or logistic regression (for binary variables). Year and colony were included as main effects. Two-way interactions were tested for all models, but only significance was reported. We evaluated linear and quadratic terms in linear regression to infer trends through time ( $\mathrm{n}=$ 11). Time series were tested for first-order serial autocorrelation (Prais-Winsten regression for small sample sizes). None of the autocorrelation coefficients were significant $\left(p_{\text {all }}>0.5\right)$. Indices of prey availability were transformed (natural log) prior to analyses. Parameters expressed as proportions (p) (e.g. diet composition) were logit-transformed $[\ln (\mathrm{p} /(1-\mathrm{p})]$ prior to analyses (Stata Statistical Software v.8.0). Spearman's rho $\left(\mathrm{r}_{\mathrm{S}}\right)$ was used to indicate the degree of covariation between the colonies. We tested for both linear and curvilinear relationships between upwelling, prey and auklet reproductive parameters. We used multiple regression to investigate effects of multiple prey species on auklet growth and reproductive success. Models were selected using forward and backward stepwise selection. Given the relatively short time series examined, significance was defined as $\mathrm{p}<0.10$.

\section{RESULTS}

\section{Interannual and spatial variability}

\section{Upwelling and SST}

Ocean climate varied both temporally and spatially. From 1993 to 1998 and in 2003 upwelling was reduced and SST was warmer, while the opposite was true for 1999 to 2002 (Fig. 2). Upwelling increased through time from February to March (Linear regression: $\beta=4.41, \mathrm{p}=0.090, \mathrm{r}^{2}=0.29$ ) and June to July $\left(\beta=6.74, p=0.008, R^{2}=0.57\right)$, while SST decreased through time at SFI $\left(\beta_{\text {Feb-Mar }}=-0.15, \mathrm{p}=0.089, \mathrm{r}^{2}=\right.$ $0.29 ; \beta_{\text {Jun-Jul }}=-0.14, p=0.031, R^{2}=0.42$ ) and at ANI $\left(\beta_{\text {Apr-May }}=-0.16, p=0.092, R^{2}=0.28\right)$. The UI was inversely correlated with SST around both islands (Spearman correlation for each season: all $r_{S}>0.87$, $\mathrm{p}<0.001)$. Because we could not derive upwelling at a small scale, we used local SST as our proxy for ocean climate in intercolony comparisons. SST was slightly higher around ANI than SFI, but covaried through time (Fig. 2).

Forage fish availability and auklet prey harvest

Juvenile rockfish abundance decreased in the 1990s and increased in the early 2000s, reflecting a significant quadratic trend $\left(\beta_{\mathrm{yr}}=-409.61, \mathrm{p}=0.020 ; \beta_{\mathrm{yr}}^{2}=\right.$ $0.10, \mathrm{p}=0.020$; Fig. 3a). Anchovy abundance decreased significantly through time $(\beta=-0.24, p=0.040$; Fig. 3b) similar to an apparent decline in macrozooplankton (Smith \& Moser 2003).

From 1993 through 2003, we collected 2133 prey items in 642 bill loads on SFI, and 1170 prey items in 318 bill loads on ANI. Rhinoceros auklets provisioned offspring with 39 prey species; 34 species were documented at offshore SFI and 31 at inshore ANI. Over $10 \%$ of the diet (for at least $1 \mathrm{yr}$ ) was comprised of small coastal pelagic species northern anchovy Engraulis mordax, Pacific saury Cololabis saira, and Pacific sardine Sardinops sagax; juvenile rockfish, i.e. Sebastes jordani, S. entomelas, S. flavidus, S. hopkinsi, or S. mystinus; sablefish Anoplopoma fimbria; chinook salmon Oncorhynchus tshawytscha; lingcod Ophiodon elongatus; and market squid Loligo opalescens (Fig. 4). Sablefish occurred in larger proportions at SFI, while more rockfish species were observed at ANI. Bill load mass varied significantly between years and was lower at ANI than SFI $\left(F\right.$ [year $_{(10,672)}=2.74, \mathrm{p}=0.003 ; F[\operatorname{colony}]_{(1,672)}=6.61$, $\mathrm{p}=0.010 ;$ Fig. 5a).

We examined in more detail the take of main prey species, i.e. those that comprised at least $40 \%$ of chick diet in at least 1 yr. These included rockfish, anchovy and saury. Prey harvest covaried between sites, although more rockfish and anchovy were taken at ANI and more saury were taken at SFI (Fig. 3). A positive trend in rockfish take $\left(\beta_{\mathrm{yr}}=0.38, \mathrm{p}=0.050\right)$ and $\mathrm{a}$ decrease in anchovy take were seen at ANI $\left(\beta_{\mathrm{yr}}=\right.$ $-0.29, p=0.015)$. Increasing trends in use of saury were documented at both sites (SFI: $\beta_{\mathrm{yr}}=0.48, \mathrm{p}=$ 0.018; ANI: $\left.\beta_{\mathrm{yr}}=0.28, \mathrm{p}=0.098\right)$. 

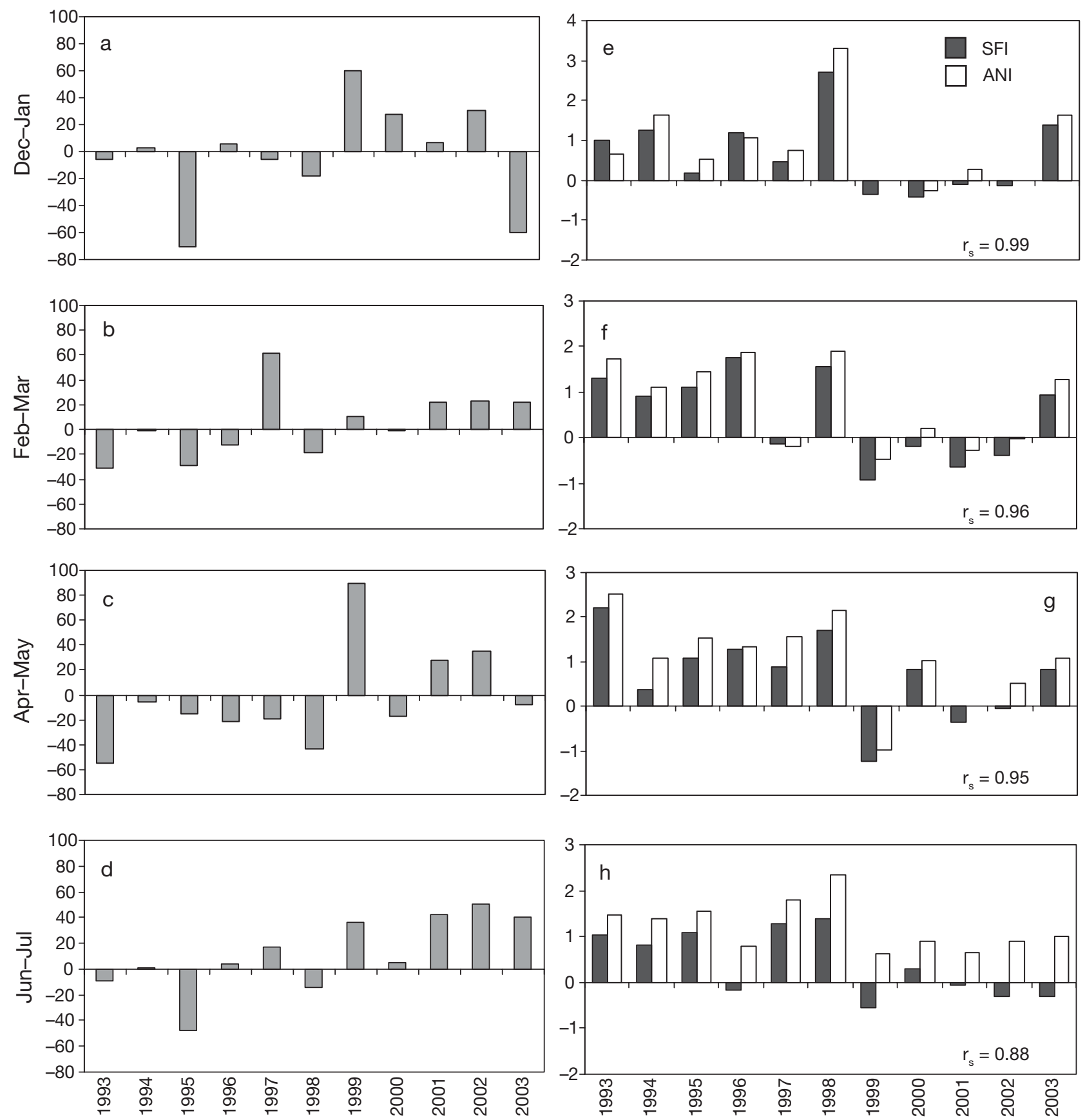

Fig. 2. Anomalies over 2-mo periods of (a-d) average upwelling index values $\left(\mathrm{m}^{3} \mathrm{~s}^{-1} 100 \mathrm{~m}^{-1}\right)$ between 36 and $39^{\circ} \mathrm{N}$ using 1967-2003 climate data and (e-h) SST $\left({ }^{\circ} \mathrm{C}\right)$ within $50 \mathrm{~km}$ around SFI and ANI using 1955-2003 climate data. Spearman's rho $\left(\mathrm{r}_{\mathrm{S}}\right)=$ covariation of sea surface temperature $(\mathrm{SST})$ at SFI and ANI

\section{Seabird reproduction}

Timing of breeding and offspring growth and survival varied significantly between years and colonies, but without time trends (Fig. 5). Timing covaried between colonies but was earlier at ANI in most years by approximately $5 \mathrm{~d}$ (Fig. 5b). Timing was latest during the 1998 ENSO event, and has become earlier in recent years. Offspring growth also covaried between colonies, and was lowest in 2003 (Fig. 5c). Offspring survival was lower and more variable between years at SFI (coefficient of variation, $\mathrm{CV}$ range $=3-21 \%)$ than ANI $(\mathrm{CV}$ range $=$ $0-7 \%$; Fig. 5d). 

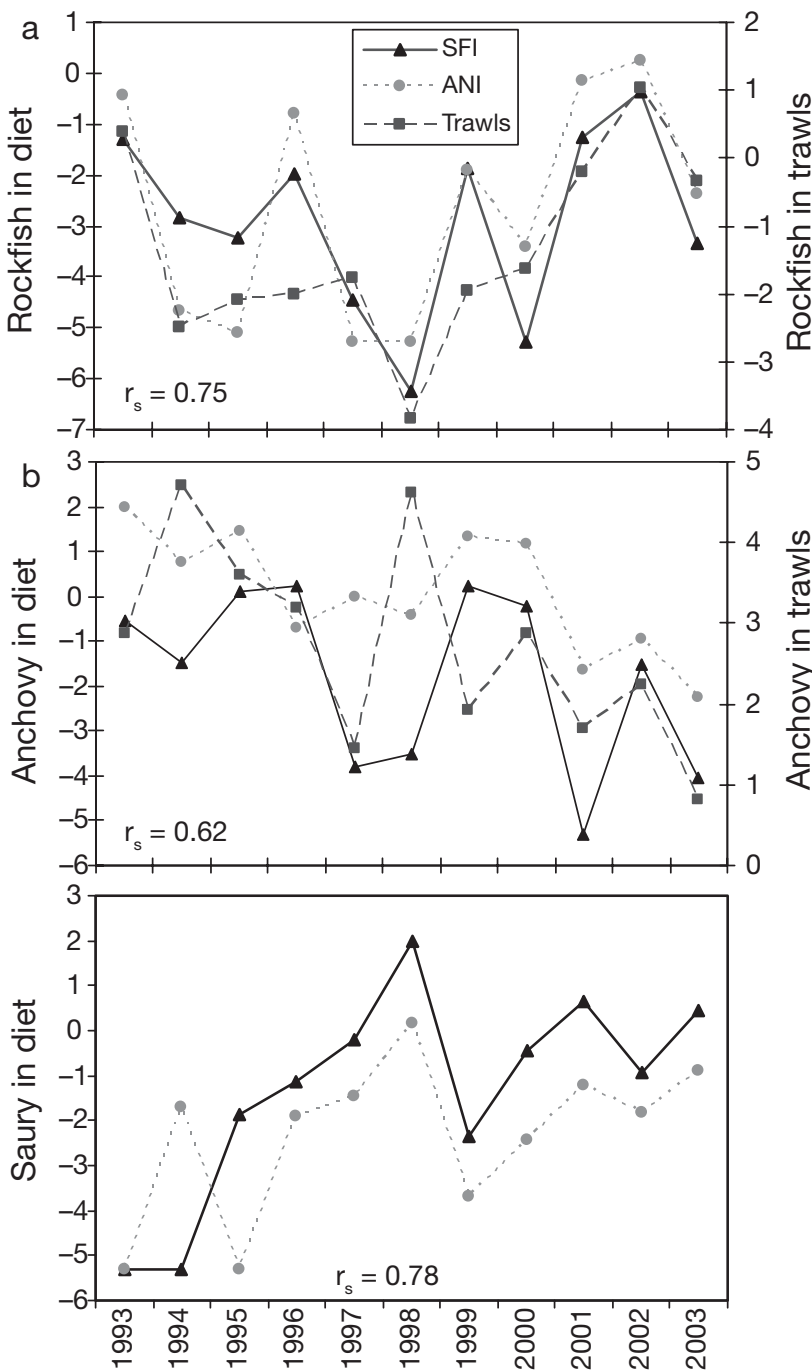

Fig. 3. Cerorhinca monocerata, Sebastes spp., Engraulis mordax, and Cololabis saira. Predator take (logit-transformed\% mass) and trawl survey abundance indices (log-transformed) from 1993-2003 of (a) juvenile rockfish (b) anchovy (c) saury. Spearman's rho $\left(\mathrm{r}_{\mathrm{S}}\right)=$ covariation of predator take between SFI and ANI

\section{SST and seabird diet, and reproduction}

The take of rockfish by seabirds at both sites was negatively correlated with SST from June to July (Table 1; Fig. 6). Take of saury was positively correlated with SST, significantly so at ANI. Timing of breeding was significantly later with increasing SST from December to March, more so in February to March at ANI (Table 2; Fig. 7). Offspring survival was negatively correlated with SST in April to May, especially at SFI (Table 3, Fig. 8). The relationship at SFI initially appeared to be driven by 1998 values, but removal of each year in sequential analyses produced similar results.

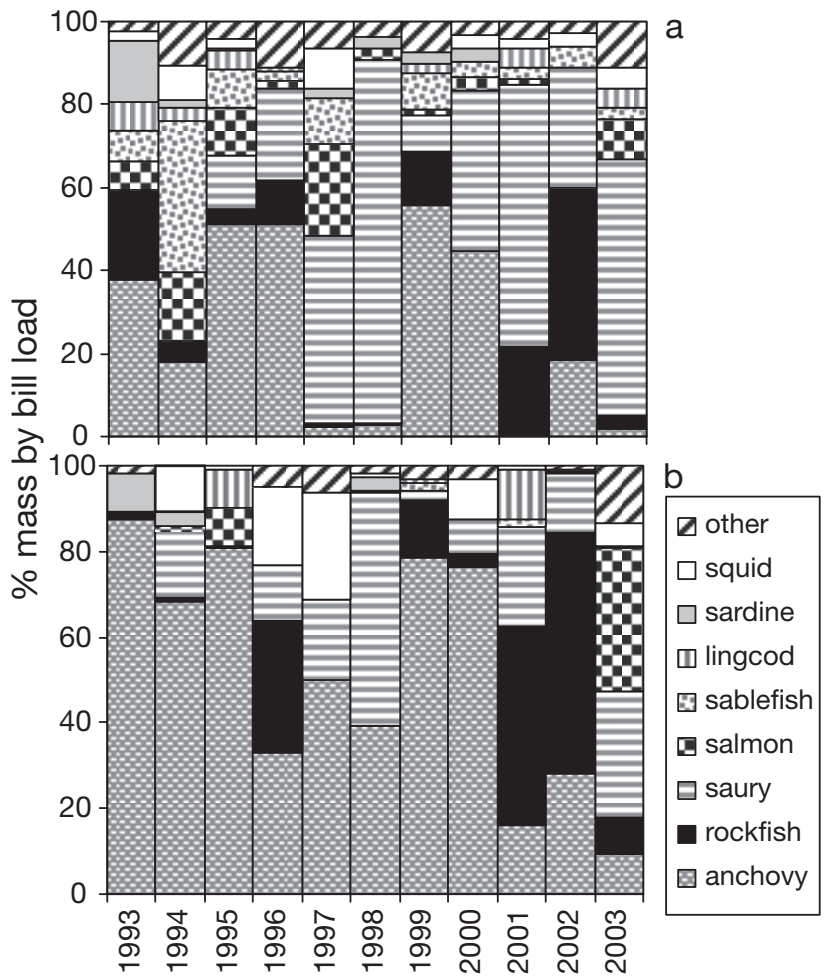

Fig. 4. Cerorhinca monocerata. Offspring diet composition in percent mass of prey by bill load on (a) SFI and (b) ANI from 1993-2003

\section{Prey availability and seabird diet}

Prey harvest by auklets was related to prey availability in the environment as measured by trawl surveys. Positive linear relationships between rockfish harvest and availability were evident at SFI $(\beta=0.94$, $\left.\mathrm{p}=0.011, \mathrm{R}^{2}=0.53\right)$ and ANI $\left(\beta=1.21, \mathrm{p}=0.005, \mathrm{R}^{2}=\right.$ 0.60 ; Fig. 9a). We found curvilinear relationships between anchovy availability and predator take at SFI $\left(\beta=5.54, p=0.019 ; \beta^{2}=-0.86, p=0.029 ; R^{2}=0.54\right)$ and ANI $\left(\beta=1.21, p=0.069 ; \beta^{2}=-0.45, p=0.107\right.$; $\mathrm{R}^{2}=0.42$; Fig. 9b). The years 1998 and 1994 were primarily responsible for the curvilinear nature of these relationships.

\section{Relationships between reproductive parameters}

Although relationships were not significant, auklet offspring growth generally increased with later timing of hatching, except during the 1998 ENSO event. This result was not expected but may be related to earlyseason exploitation of rockfish, when available, and prey switching to anchovy later in the offspringrearing period. Growth increased when the diet contained more anchovy $\left(\mathrm{r}_{\mathrm{s} \text { ANI }}=0.82, \mathrm{p}=0.002 ; \mathrm{r}_{\mathrm{s} \text { SFI }}=\right.$ 0.89, p $<0.001$; Fig. 10a). Offspring growth was lower 

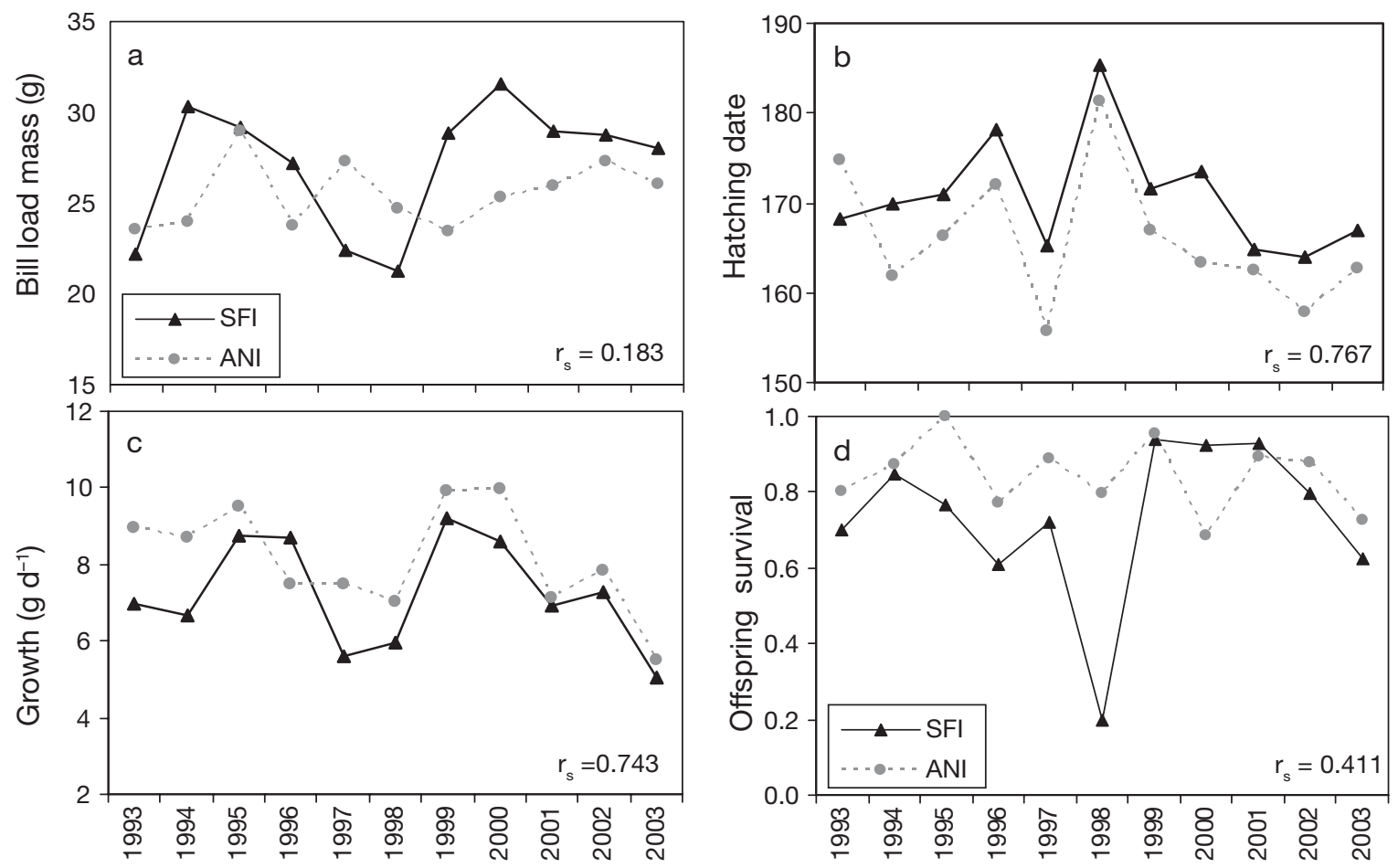

Fig. 5. Cerorhinca monocerata. Time series of (a) bill load mass (b) hatching date (c) offspring growth rate (d) offspring survival on ANI and SFI, 1993-2003. Day 150 = 30 May. Spearman's rho $\left(\mathrm{r}_{\mathrm{S}}\right)$ : degree of covariation between colonies

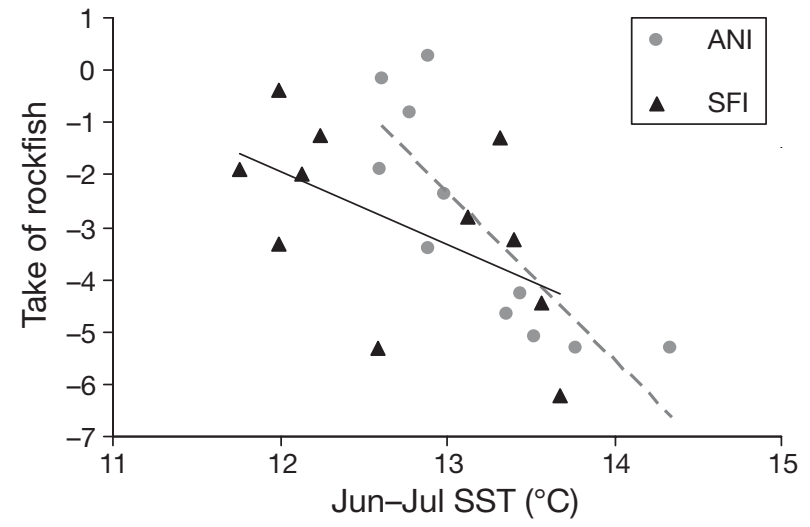

Fig. 6. Sebastes spp. Relationships of take of rockfish (logittransformed \% mass) with Jun-Jul SST at ANI and SFI, 1993-2003. Trendlines: Spearman rank correlations at $\mathrm{p} \leq$ 0.10 (solid: SFI; dashed: ANI)

Table 1. Engraulis mordax, Sebastes spp. and Cololabis saira. Spearman rank correlations of prey take with sea surface temperature (SST) at Año Nuevo Island (ANI) and Southeast Farallon Island (SFI), 1993-2003. All prey were logit-transformed. Significance: $\mathrm{p} \leq 0.05$ (dark gray) or $\mathrm{p} \leq 0.10$ (light gray)

\begin{tabular}{|c|c|c|c|c|c|c|}
\hline & \multicolumn{3}{|c|}{ ANI $(\mathrm{n}=11)$} & \multicolumn{3}{|c|}{ SFI $(n=11)$} \\
\hline & Anchovy & Rockfish & Saury & Anchovy & Rockfish & Saury \\
\hline Dec-Jan SST & -0.28 & -0.45 & 0.53 & -0.28 & -0.42 & 0.13 \\
\hline Feb-Mar SST & 0.07 & -0.38 & -0.08 & 0.16 & -0.25 & -0.14 \\
\hline Apr-May SST & 0.17 & -0.63 & -0.06 & 0.06 & -0.38 & -0.06 \\
\hline Jun-Jul SST & 0.19 & -0.83 & 0.14 & -0.10 & -0.56 & -0.12 \\
\hline
\end{tabular}

Table 2. Cerorhinca monocerata. Spearman rank correlations of timing of breeding with SST at ANI and SFI, 1993-2003.

Significance: $\mathrm{p} \leq 0.05$ (dark gray) or $\mathrm{p} \leq 0.10$ (light gray)

\begin{tabular}{|lcc|}
\hline & \multicolumn{2}{c|}{ Mean hatch date- } \\
\cline { 2 - 3 } & ANI $(\mathrm{n}=11)$ & SFI $(\mathrm{n}=11)$ \\
\hline Dec-Jan SST & 0.57 & 0.59 \\
Feb-Mar SST & 0.72 & 0.55 \\
Apr-May SST & 0.45 & 0.37 \\
\hline
\end{tabular}

when diet contained more saury $\left(\mathrm{r}_{\mathrm{s} \text { ANI }}=-0.86, \mathrm{p}=\right.$ $0.001 ; \mathrm{r}_{\mathrm{s} \text { SFI }}=-0.52, \mathrm{p}=0.102$; Fig. 10b), which was often the case in relatively warm-water years. No relationship between growth and rockfish in the diet or SST was apparent. However, multiple regression models (both forward and backward) showed significant positive effects for both anchovy and rockfish on auklet growth; rockfish had more influence on ANI than on SFI (Table 4). Growth was not significantly related to offspring survival at either colony.

With models examining influences on offspring survival, we determined that the strongest effects were SST and bill load mass (Table 5). This relationship 


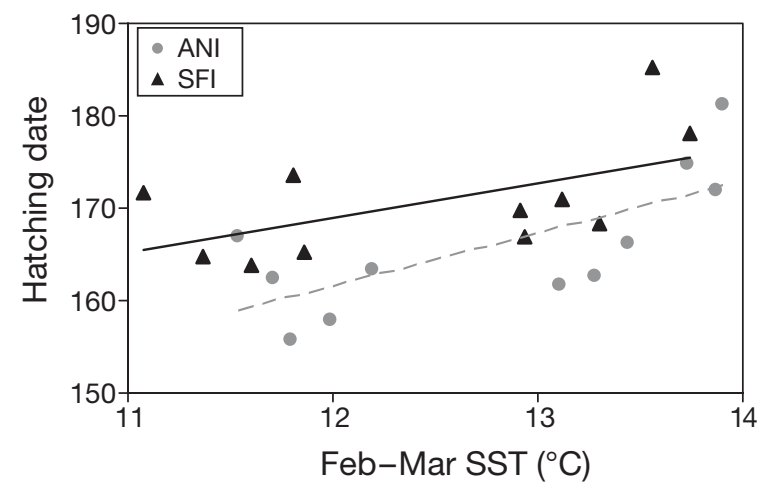

Fig. 7. Cerorhinca monocerata. Relationships of timing with Feb-Mar SST at ANI and SFI, 1993-2003. Day $150=30$ May. Trendlines: Spearman rank correlations at $\mathrm{p} \leq 0.10$ (solid: SFI; dashed: ANI)

Table 3. Cerorhinca monocerata. Spearman rank correlations of offspring survival (logit-transformed) with SST at ANI and SFI, 1995-2003. Significance: $\mathrm{p} \leq 0.05=$ dark gray

\begin{tabular}{|lcc|}
\hline & \multicolumn{2}{c|}{ Offspring survival -} \\
\cline { 2 - 3 } & ANI $(\mathrm{n}=11)$ & SFI $(\mathrm{n}=11)$ \\
\hline Dec-Jan SST & -0.28 & -0.79 \\
Feb-Mar SST & -0.49 & -0.89 \\
Apr-May SST & -0.23 & -0.86 \\
Jun-Jul SST & -0.03 & -0.43 \\
\hline
\end{tabular}

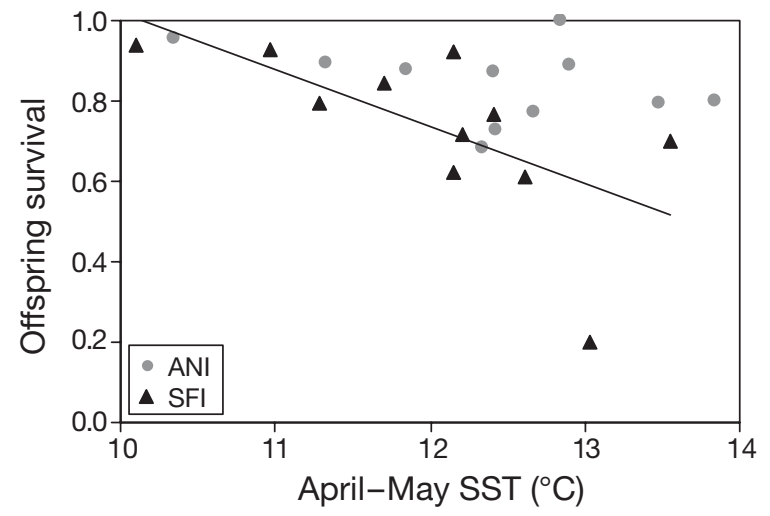

Fig. 8. Cerorhinca monocerata. Relationships between proportion of offspring surviving and Apr-May SST on ANI and SFI, 1993-2003. Trendlines: Spearman rank correlations at $\mathrm{p} \leq 0.10$ (solid line: $\mathrm{SFI})$

was stronger at offshore SFI. The interactions between SST and bill load mass were not significant, and inclusion of SST in the models considerably boosted explanatory power over bill load mass alone. SST in April to May was more influential on offspring survival at ANI, while February to March SST was more influential at SFI.
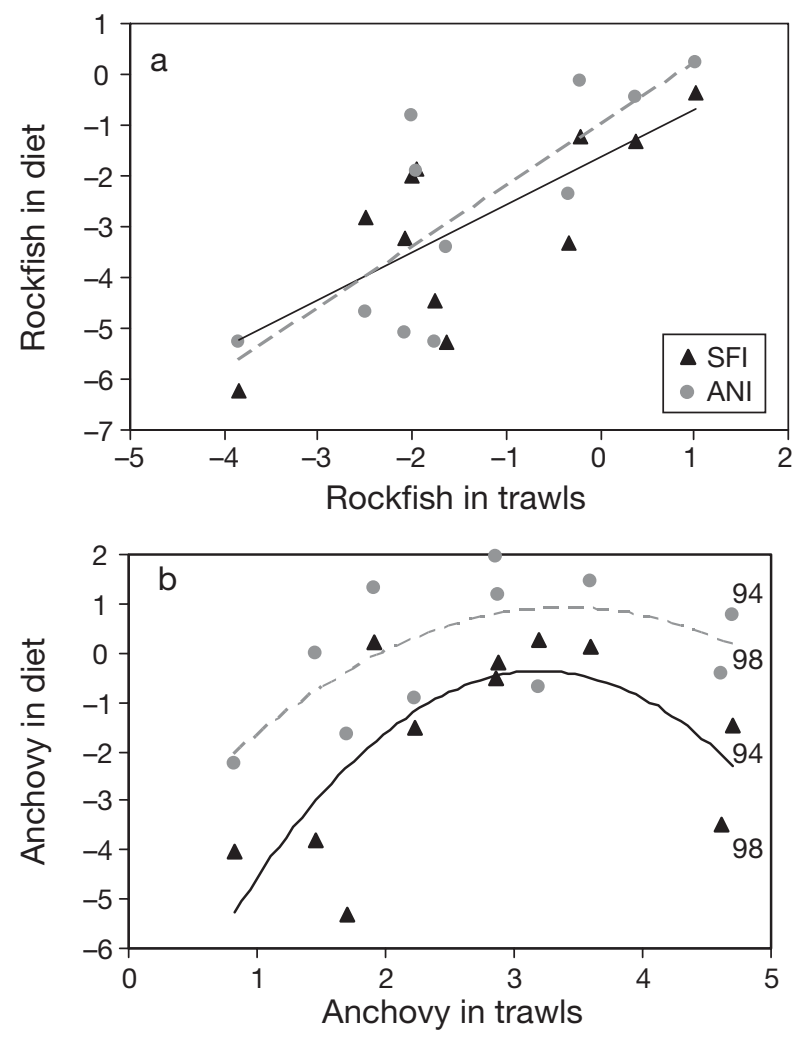

Fig. 9. Cerorhinca monocerata, Sebastes spp. and Engraulis mordax. Relationships of predator take (logit-transformed $\%$ mass) with trawl survey abundance indices (log-transformed) from 1993-2003 for (a) rockfish and (b) anchovy. Trendlines: Spearman rank correlations for linear trends or quadratic regressions for curvilinear trends at $\mathrm{p} \leq 0.10$ (solid: SFI; dashed: ANI). Selected years are labeled $(94,98)$

\section{DISCUSSION}

We investigated the hypothesis of spatial differences in prey harvest and reproductive ecology of rhinoceros auklets relative to local prey availability and upwelling. To test this hypothesis we integrated data on SST, forage fish abundance and diet and life history responses of the auklets. Our proxy for upwelling, SST, was correlated with auklet harvest of juvenile rockfish and with reproductive timing and performance. Relationships differed between colonies: the effects of SST on timing and rockfish harvest were stronger at inshore ANI, while SST and bill load mass were related to offspring survival at offshore SFI.

\section{Influence of temporal ocean variability on reproductive ecology}

Upwelling and cold-water conditions in the CCS have been associated with high primary and secondary 


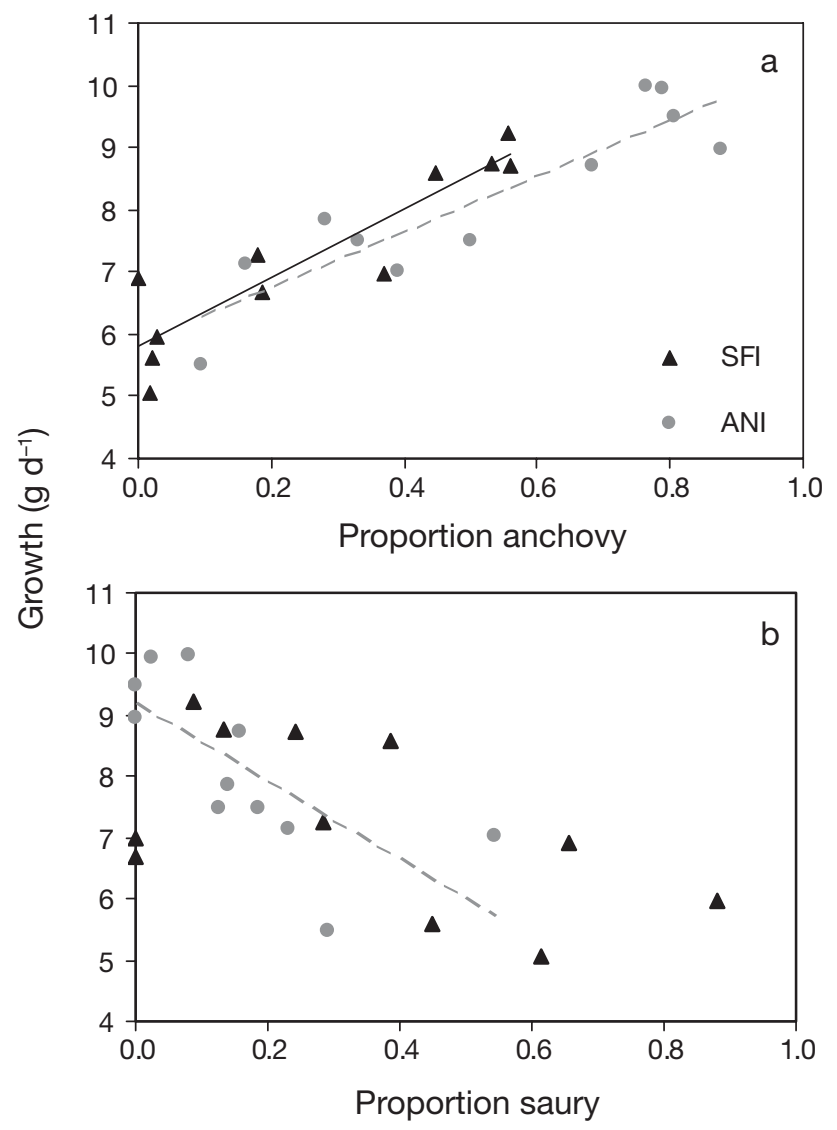

Fig. 10. Cerorhinca monocerata, Engraulis mordax and Cololabis saira. Relationships of offspring growth with take of (a) anchovy and (b) saury at ANI and SFI, 1993-2003. Trendlines: Spearman rank correlations at $\mathrm{p} \leq 0.10$ (solid: $\mathrm{SFI}$; dashed: ANI)

productivity (Chavez et al. 2002, Collins et al. 2003). Auklet harvest of rockfish was negatively correlated with SST (Fig. 6). Take of anchovy did not correlate with SST, unlike the positive relationship demonstrated at Teuri Island, Japan, where anchovy migration follows the warm-water Tsushima Current (Deguchi et al. 2004).

There was significant interannual variability in auklet reproductive parameters, but unlike ocean climate and prey availability, bird reproduction did not exhibit trends through time (Fig. 5). However, timing of hatching was positively related to SST (Fig. 7). This finding is similar to results for Cassin's auklet Ptychoramphus aleuticus at SFI (Abraham \& Sydeman 2004) as well as for cormorants, kittiwakes and murres in the Northeast Atlantic (Fredericksen et al. 2004). In all cases, timing of breeding was linked to marine conditions just prior to egg laying. Rhinoceros auklet timing of breeding at Triangle Island off British Columbia was also related to spring SST (Bertram et al. 2001); here, however breeding was earlier with increasing SST, in contrast to our observations. Warm spring conditions off British Columbia favor an early peak in zooplankton biomass, resulting in a shorter period of overlap between zooplankton abundance and sandlance, the main prey of rhinoceros auklets in that part of the CCS (Bertram et al. 2001). In our study area the central CCS, warm conditions reflect limited nutrient input to the photic zone and low primary productivity (Chavez et al. 2002). This may delay or preclude fish spawning as well as reduce juvenile fish survival (Cury \& Roy 1989, Wroblewski et al. 1989, Lenarz et al. 1995), thereby delaying auklet breeding here.

We found that auklet offspring survival was also correlated with variation in SST in the central CCS (Table 3, Table 5). Other studies have sought relationships between environmental variables and reproductive success of marine birds with varying results. Rhinoceros auklets and related puffins exhibited reduced offspring growth and survival with increased SST off British Columbia, due to a hypothesized mismatch in the predator-prey relationship (Bertram et al. 2001, Gjerdrum et al. 2003). Decker et al. (1995) documented a decrease in kittiwake reproductive performance in the Bering Sea during a period of above-average SST, but breeding success remained depressed after SST returned to average values.

The aforementioned studies, however, were based on covarying time trends, which we did not observe. A climate regime change in 1998 to 1999 as described by Peterson \& Schwing (2003) meant that the 11 yr of our study are divided into 6 yr that were relatively warm

Table 4. Cerorhinca monocerata. Results of multiple regression model examining factors affecting offspring growth at SFI and ANI, 1993-2003

\begin{tabular}{|c|c|c|c|c|c|c|c|c|c|}
\hline \multirow[t]{2}{*}{ Location } & \multirow[t]{2}{*}{ df } & \multirow[t]{2}{*}{ Model p } & \multirow[t]{2}{*}{$\mathrm{R}^{2}$} & \multicolumn{2}{|c|}{$\longrightarrow$ Colony -} & \multicolumn{2}{|c|}{ - Anchovy } & \multicolumn{2}{|c|}{ — Rockfish - } \\
\hline & & & & $\beta$ & $\mathrm{p}$ & $\beta$ & $\mathrm{p}$ & $\beta$ & $\mathrm{p}$ \\
\hline ANI \& SFI & 3,18 & $<0.001$ & 0.90 & -0.59 & 0.027 & 5.51 & $<0.001$ & 2.31 & 0.004 \\
\hline ANI & 2,8 & $<0.001$ & 0.93 & - & - & 5.75 & $<0.001$ & 2.81 & 0.008 \\
\hline SFI & 2,8 & $<0.001$ & 0.86 & - & - & 5.48 & $<0.001$ & 1.53 & 0.330 \\
\hline
\end{tabular}


Table 5. Cerorhinca monocerata. Results of multiple regression model examining factors affecting offspring survival at SFI and ANI, 1993-2003

\begin{tabular}{|c|c|c|c|c|c|c|c|c|c|c|}
\hline \multirow[t]{2}{*}{ Location } & \multirow[t]{2}{*}{$\mathrm{df}$} & \multirow[t]{2}{*}{ Model p } & \multirow[t]{2}{*}{$\mathrm{R}^{2}$} & \multicolumn{2}{|c|}{- Colony -} & \multicolumn{2}{|c|}{ Bill load mass } & \multicolumn{2}{|c|}{$-\mathrm{SST}=$} & \multirow{2}{*}{$\begin{array}{c}\text { SST } \\
\text { Season }\end{array}$} \\
\hline & & & & $\beta$ & $\mathrm{p}$ & $\beta$ & $\mathrm{p}$ & $\beta$ & $\mathrm{p}$ & \\
\hline ANI and SFI & 3,19 & 0.001 & 0.74 & 0.80 & 0.001 & 0.13 & 0.002 & -0.41 & 0.002 & Feb-Mar \\
\hline ANI and SFI & 3,19 & 0.002 & 0.69 & 0.82 & 0.002 & 0.13 & 0.005 & -0.36 & 0.009 & Apr-May \\
\hline ANI & 2,9 & 0.064 & 0.60 & - & - & 0.21 & 0.045 & -0.37 & 0.057 & Apr-May \\
\hline SFI & 2,9 & $<0.001$ & 0.83 & - & - & 0.12 & 0.016 & -0.56 & 0.005 & Feb-Mar \\
\hline
\end{tabular}

(1993-1998) and the following 5 cooler years (1999-2003; Fig. 2). Instead of trends driving relationships, we observed interannual correlations of marine climate with rhinoceros auklet ecology. Similarly, Pinaud \& Weimerskirch (2002) showed that years of anomalously cold SST affected albatross breeding success in the Southern Ocean. In addition, Guinet et al. (1998) found reduced petrel productivity relative to increased SST associated with ENSO effects.

\section{Spatial variation in prey}

Rockfish have been found to occur in high abundances around both islands (Chess et al. 1988, Yoklavich et al. 1996). Mills et al. (in press) found a high correlation between rockfish take at SFI and rockfish abundance based on NMFS trawls between 1987 and $2002\left(R^{2}=0.78, p<0.001\right)$, and we found the same results in the present study using a slightly different time series and index of rockfish abundance. Rockfish harvest by birds at ANI was higher than at SFI in many years, and was more strongly correlated with SST (Fig. 6) and the rockfish abundance index (Fig. 9a). These differences may be explained by local variation in upwelling. As ANI is near the shore, effects of coastal upwelling may occur there sooner than at offshore SFI. Also, upwelling usually starts earlier along the southern sector of the central California coast (Schwing et al. 1996). The seabirds' timing of breeding was earlier at ANI, which may facilitate a better temporal match with juvenile rockfish availability, since most rockfish settle out of the water column between May and July (Love et al. 2002). Moreover, in years of high southward wind stress, major upwelling fronts that concentrate prey may intensify and move offshore, but during less persistent or weaker upwelling, fronts remain inshore (Steger et al. 2000). Therefore, between 1999 and 2002, when there was higher than average upwelling (Fig. 2a-d), frontal zones offshore may have contributed to higher bird productivity at SFI.

The anchovy index we developed was correlated with bird diet at both colonies, though in a nonlinear fashion (Fig. 9b). While both anchovy and juvenile rockfish thrive under cooler conditions, anchovy have behavioral strategies such as plasticity in feeding, i.e. either filter or selective feeding, migration, and shoaling behavior (Robinson 2004), which allow them to better withstand variable and/or warmer conditions. Anchovy may thus be more abundant in warmer conditions when juvenile rockfish are not available, providing an alternate food source for auklets. The relationship between anchovy in the diet and in net trawls was stronger at SFI, although there was often more take of anchovy by birds at ANI (Fig. 3b). Anchovy are usually distributed fairly nearshore (Mais 1990). Furthermore, north- and coastward shifts of larval anchovies in warm-water years (see Kope \& Botsford 1990) may have actually rendered anchovy more available to auklets in central California. This may particularly be true nearshore of ANI throughout the breeding season, when other cooler-water species such as rockfish were not available. Indeed, while no rockfish were observed in the auklet diet during the 1998 ENSO, a relatively high proportion of anchovy was sampled on ANI (Fig. 4). Anchovy presence in the ANI auklet diet during the 2003 ENSO was much lower, although still higher than at SFI. Lower frequency (multi-decadal) environmental variation likely also influences anchovy abundance.

Spatial variation in the harvest of other prey species was also evident, with diet sampled at SFI being slightly more diverse than that at ANI. Auklet take of both saury and juvenile sablefish was higher at SFI (Fig. 5). Sablefish were a large component of the auklet diet at SFI prior to our study (mean $22 \%$ of diet from 1987 to $1992 ;$ J. Thayer \& W. Sydemann, PRBO Conservation Science, unpubl. data) but their importance has decreased (mean 8\% of diet from 1993 to 2003), perhaps related to decreased abundance and/or availability. Take of saury increased as sablefish decreased. As an alternative prey resource, saury is a primarily offshore species (Hughes 1973) and thus is distributed near SFI, although it is a low-lipid fish that is not energetically profitable (Table 6). Inshore ANI may be closer to the distribution of high-lipid anchovy in warm-water years. 
Table 6. Energetic values of auklet prey fishes from the literature. Cal/g: calories per gram; FL: fork length; SL: standard length; NMFS: National Marine Fisheries Service; SWFSC: Southwest Fisheries Science Center

\begin{tabular}{|c|c|c|c|c|c|c|c|}
\hline Species & $\mathrm{Cal} / \mathrm{g}$ & $\begin{array}{c}\text { \% lipid } \\
\text { (wet mass) }\end{array}$ & $\begin{array}{l}\text { Location } \\
\text { sampled }\end{array}$ & $\begin{array}{c}\text { Mo } \\
\text { sampled }\end{array}$ & $\begin{array}{c}\text { Yr } \\
\text { sampled }\end{array}$ & $\begin{array}{l}\text { Size } \\
(\mathrm{mm})\end{array}$ & Source \\
\hline \multicolumn{8}{|l|}{ Pacific saury } \\
\hline Cololabis saira & 4813 & - & Triangle Island, BC & Jul-Aug & $1977-1979$ & $180 \mathrm{FL}$ & Vermeer \& Devito (1986) \\
\hline \multirow[t]{3}{*}{$\begin{array}{l}\text { Sandlance } \\
\text { Ammodytes } \\
\text { hexapterus }\end{array}$} & - & 1.2 & $\begin{array}{l}\text { Southern Kodiak } \\
\text { Archipelago to East- } \\
\text { ern Aleutians, AK }\end{array}$ & Jul - Aug & 1993-1994 & $82 \mathrm{SL}$ & Van Pelt et al. (1997) \\
\hline & $\begin{array}{l}- \\
-\end{array}$ & $\begin{array}{l}4.7 \\
6.5\end{array}$ & & & & $\begin{array}{l}122 \mathrm{SL} \\
165 \mathrm{SL}\end{array}$ & \\
\hline & $\begin{array}{l}4700 \\
5383\end{array}$ & $\begin{array}{l}- \\
-\end{array}$ & $\begin{array}{c}\text { Triangle Island, } \\
\text { BC }\end{array}$ & Jul-Aug & $1977-1979$ & $\begin{array}{l}80 \mathrm{FL} \\
155 \mathrm{FL}\end{array}$ & Vermeer \& Devito (1986) \\
\hline $\begin{array}{l}\text { Widow rockfish } \\
\text { Sebastes entomelas }\end{array}$ & 5200 & - & $\begin{array}{c}\text { Triangle Island, } \\
\text { BC }\end{array}$ & Jul-Aug & $1977-1979$ & $75 \mathrm{FL}$ & \\
\hline \multirow[t]{2}{*}{$\begin{array}{l}\text { Yellowtail rockfish } \\
\text { Sebastes flavidus }\end{array}$} & 5292 & - & $\begin{array}{l}\text { Monterey Bay to } \\
\text { Point Reyes, } \\
\text { Central CA }\end{array}$ & May-Jun & 1989 & $39 \mathrm{SL}$ & $\begin{array}{l}\text { NMFS/SWFSC } \\
\text { (unpubl. data) }\end{array}$ \\
\hline & 5398 & - & $\begin{array}{l}\text { Cordell Bank, } \\
\text { Central CA }\end{array}$ & May-Jun & 1989 & $39 \mathrm{SL}$ & \\
\hline $\begin{array}{l}\text { Shortbelly rockfish } \\
\text { Sebastes jordani }\end{array}$ & - & 5 & Central CA & $\sim$ May-Jul & $1993-1996$ & $70 \mathrm{SL}$ & Norton et al. (2001) \\
\hline $\begin{array}{l}\text { Nothern anchovy } \\
\text { Engraulis mordax }\end{array}$ & - & $\sim 7.5$ & Baja CA & Jun-Aug & $1981-1988$ & Unknown & Garcia-Franco et al. (1999) \\
\hline $\begin{array}{l}\text { Japanese anchovy } \\
\text { Engraulis japonicus }\end{array}$ & 6290 & - & $\begin{array}{l}\text { Teuri Island, } \\
\text { Japan }\end{array}$ & Jun-Jul & $1996-1997$ & $\begin{array}{c}127-149 \\
\text { FL }\end{array}$ & Takahashi et al. (2001) \\
\hline
\end{tabular}

\section{Spatial variation in predator responses}

Diet composition influenced auklet offspring growth. Growth at both SFI and ANI was positively correlated with the proportion of anchovy in the diet, a large, high-lipid prey. Our results corroborate those of Takahashi et al. (2001) for Japanese anchovy Engraulis japonicus and rhinoceros auklet offspring growth in the Tsushima Current. In the CCS, however, auklet offspring were not necessarily fed the largest prey or the prey with the highest protein and energy values (as suggested by Takahashi et al. 2001). Growth was also positively related to the much smaller rockfish in the diet (Table 4). This was more pronounced at ANI where take of rockfish was often higher than at SFI. While caution should be taken with interpretation of energetic values of prey species sampled using different methods or locations, years, or seasons (Van Pelt et al. 1997), juvenile rockfish generally have a lower energetic value than anchovy, but higher than other prey items (Table 6). Offspring growth was negatively related to saury in the diet (Fig. 10b), more so at SFI where the proportion of saury in the diet was higher. Saury had a lower energetic value than other puffin prey described in the literature, although proximate composition data were not available (Table 6).

Neither timing of breeding nor growth was strongly related to offspring survival at either colony. While diet composition was related to growth in our study, the mass of food that chicks received was more important for survival (Table 5), supporting the explanation of prey-switching tactics. A minimum threshold in offspring weight or development may be more important than growth rates for successful breeding each year. Additionally, the lack of a strong relationship between offspring growth and survival may be more pronounced when there are large size differences in preferred prey species, as with anchovy and rockfish. In the Tsushima Current, rhinoceros auklets preyed heavily on anchovy (1990s) or sardine (1980s), which are similar in size, but they also preyed on a high proportion of smaller sandlance (Deguchi et al. 2004). Energetic value of sandlance may be equal to or less than that of rockfish, depending on sandlance age or size (Table 6). Unlike SFI and ANI, however, offspring growth and survival at Teuri Island were significantly correlated $\left(\mathrm{R}^{2}=0.315, \mathrm{n}=15\right.$ years $)$. In British Colum- 
bia, the offspring growth and survival of the tufted puffin Fratercula cirrhata were also highly correlated (Gjerdrum et al. 2003). These puffins, however, feed mainly on sandlance and are apparently not very successful at switching prey when sandlance are unavailable.

In our study, prey-switching abilities appeared to vary between years and colonies. Suitable alternative prey were apparently insufficient during the extreme 1998 ENSO event at offshore SFI when saury made up $>85 \%$ of the diet. Stronger relationships of timing and diet composition with ocean climate were seen inshore at ANI, while a stronger relationship of offspring survival to ocean climate was apparent at SFI. Rockfish and anchovy take, and offspring growth and survival were also all higher inshore. This suggests that environment around ANI may be less variable, allowing birds to better buffer environmental conditions by adjusting their diet, thereby increasing productivity.

In conclusion, we observed significant interannual variation in upwelling, forage fish availability and rhinoceros auklet reproduction in the central CCS from the early 1990s to the early 2000s. Notably, both net surveys and auklet diet showed similar patterns; rockfish abundance fluctuated during our study, while anchovy abundance decreased. Adjustments in auklet diet may reduce negative effects of climate variability on reproduction. However, environmental thresholds, below which prey-switching was ineffective, occurred during extreme climate conditions. These responses were more apparent offshore than inshore. Overall, we observed differences in rhinoceros auklet diet and reproduction between colonies, which may be related to local upwelling regimes and prey distribution. Predictable, persistent food sources near breeding colonies are important for central-place foraging seabirds that are provisioning offspring which might otherwise die during intermittent periods when food is not available. In other words, inshore conditions may be more predictable, even if production offshore is sometimes higher.

Acknowledgements. We gratefully acknowledge J. Buffa and the US Fish and Wildlife Service, Farallon National Wildlife Refuge, and G. Strachan and Año Nuevo State Park for logistical and financial support. We thank M. Hester and numerous other biologists and interns who helped collect data. This research was funded in part by the Roberts Foundation, Oracle Corporation, Exxon/Mobil Corporation, National Fish and Wildlife Foundation and Monterey Bay National Marine Sanctuary. We thank S. Ralston, K. Sakuma, T. Laidig and J. Field, NMFS Santa Cruz Laboratory for providing juvenile rockfish abundance indices and for their help identifying juvenile rockfish. P. Smith (NMFS La Jolla Laboratory and Scripps Institution of Oceanography) generously shared anchovy data from CalCOFI trawl surveys. This is PRBO publication number 1210.

\section{LITERATURE CITED}

Abraham CL, Sydeman WJ (2004) Ocean climate, euphausiids and auklet nesting: interannual trends and variation in phenology, diet and growth of a planktivorous seabird, Ptychoramphus aleuticus. Mar Ecol Prog Ser 274:235-250

Ainley DG, Lewis TJ (1974) The history of Farallon Island marine bird populations, 1854-1972. Condor 76:432-446

Armstrong EM (2000) Satellite derived sea surface temperature variability off California during the upwelling season. Remote Sens Environ 73:1-17

Baltz KA (1997) Ten years of hydrographic variability off central California during the upwelling season. MS thesis, Naval Postgraduate School, Monterey, CA

Barrett RT (2002) Atlantic puffin Fratercula arctica and common guillemot Uria aalge chick diet and growth as indicators of fish stocks in the Barents Sea. Mar Ecol Prog Ser 230:275-287.

Bertram DF, Mackas DL, McKinnell SM (2001) The seasonal cycle revisited: interannual variation and ecosystem consequences. Prog Oceanogr 49:283-307

Brewer GD, Smith PE (1982) Northern anchovy and Pacific sardine spawning off southern California during 19781980: Preliminary observations on the importance of the nearshore coastal region. Calif Coop Ocean Fish Invest Rep 23:160-171

Brodeur RD, Pearcy WG (1992) Effects of environmental variability on trophic interactions and food web structure in a pelagic upwelling ecosystem. Mar Ecol Prog Ser 84: 101-116

Brodeur RD, Frost BW, Hare SR, Francis RC, Ingraham WJ Jr (1996) Interannual variations in zooplankton biomass in the Gulf of Alaska, and covariation with California Current zooplankton biomass. Calif Coop Ocean Fish Invest Rep 37:80-98

Chavez FP, Pennington JT, Castro CG, Ryan JP and 6 others (2002) Biological and chemical consequences of the 1997-1998 El Niño in central California waters. Prog Oceanogr 54:205-232

Chess JR, Smith SE, Fischer PC (1988) Trophic relationships of the shortbelly rockfish, Sebastes jordani, off central California. Calif Coop Ocean Fish Invest Rep 29:129-136

Collins CA, Pennington JT, Castro CG, Rago TA, Chavez FP (2003) The California Current System off Monterey, California: physical and biological coupling. Deep-Sea Res II 50:2389-2404

Croxall JP, Trathan PN, Murphy EJ (2002) Environmental change and Antarctic seabird populations. Science 297: 1510-1514

Cury P, Roy C (1989) Optimal environmental window and pelagic fish recruitment success in upwelling areas. Can J Fish Aquat Sci 46:670-680

Decker MB, Hunt J, Hunt GL, Byrd GV Jr (1995) The relationships among sea-surface temperature, the abundance of juvenile walleye pollock (Theragra chalcogramma) and the reproductive performance and diets of seabirds at the Pribilof Islands, southeastern Bering Sea. Can J Fish Aquat Sci 121:425-437

Deguchi T, Watanuki Y, Niizuma Y, Nakata A (2004) Interannual variations of the occurrence of epipelagic fish in the diets of the seabirds breeding on Teuri Island, northern Hokkaido, Japan. Prog Oceanogr 61:267-275

Field JC, Dick EJ, Key M, Lowry M and 6 others (in press) Population dynamics of an unexploited rockfish, Sebastes jordani, in the California Current. Proc 23rd Lowell Wakefield Symp Biology, Assessment, and Management of North Pacific Rockfishes 
Forslund P, Part T (1995) Age and reproduction in birdshypotheses and tests. Trends Ecol Evol 10:374-379

Frederiksen M, Harris MP, Daunt F, Rothery P, Wanless S (2004) Scale-dependent climate signals drive breeding phenology of three seabird species. Glob Chang Biol 10:1214-1221

Garcia-Franco W, Vidal-Talamantes R, Cota-Villavicencio A, Ramon-Corrales J, Prieto-Montalvo I (1999) Variation in fat content of northern anchovy (Engraulis mordax) in relation to the Baja California environment. Calif Coop Ocean Fish Invest Rep 40:165-169

Gjerdrum C, Vallee AMJ, St. Clair CC, Bertram DF, Ryder JL, Blackburn GS (2003) Tufted puffin reproduction reveals ocean climate variability. Proc Nat Acad Sci USA 100: 9377-9382

Guinet C, Chastel O, Koudil M, Durbec JP, Jouventin P (1998) Effects of warm sea-surface temperature anomalies on the blue petrel at the Kerguelen Islands. Proc R Soc Lond Ser B: Biol Sci 265:1001-1006

Hughes SE (1973) Stock composition, growth, mortality and availability of Pacific saury, Cololabis saira, of the northeastern Pacific Ocean. Fish Bull 72:121-131

Inchausti P, Guinet C, Koudil M, Durbec J-P, Barbraud C, Weimerskirch H, Cherel Y, Jouventin P (2003) Interannual variability in the breeding performance of seabirds in relation to oceanographic anomalies that affect the Crozet and the Kerguelen sectors of the Southern Ocean. J Avian Biol 34:170-176

Kitaysky AS, Hunt GL Jr, Flint EN, Rubega MA, Decker MB (2000) Resource allocation in breeding seabirds: responses to fluctuations in their food supply. Mar Ecol Prog Ser 206: 283-296

Kope RG, Botsford LF (1990) Determination of factors affecting recruitment of chinook salmon Oncorhynchus tshawytscha in central California. Fish Bull 88:257-269

Lenarz H, Ventresca DA, Graham WM, Schwing FB, Chavez FP (1995) Explorations of El Niño events and associated biological population dynamics off central California. Calif Coop Ocean Fish Invest Rep 36:106-119

LeValley R, Evens J (1982) The nesting season: middle Pacific coast region. Am Birds 36:1011-1015

Love MS, Yoklavich M, Thorsteinson L (2002) The rockfishes of the northeast Pacific. University of California Press, Berkeley, California. $404 \mathrm{p}$.

MacFarlane GA, Beamish RJ (1992) Climatic influence linking copepod production with strong year-classes in sablefish, Anoplopoma fimbria. Can J Fish Aquat Sci 49:743-753

McFarlane Tranquillla L, Ryder JL, Boyd WS, Shisko SG, Amey K, Bertram DF, Hipfner JM (2004) Diurnal marine distributions of marked Cassin's and rhinoceros auklets breeding at Triangle Island, British Columbia. Can Wildl Serv Tech Rep Ser No. 423

Mais A (1990) Dynamic geography of marine fish populations. Washington Sea Grant, University of Washington Press, Seattle

McGowen JA, Bograd SJ, Lynn RJ, Miller AJ (2003) The biological response to the 1977 regime shift in the California Current. Deep-Sea Res II 50:2567-2582

Mills KL, Laidig T, Ralston S, Sydeman WJ (in press) Diets of top predators indicate pelagic juvenile rockfish (Sebastes spp.) abundance in the California Current System. Fish Oceanogr

Monaghan P, Wright PJ, Bailey MC, Uttley JD, Walton P, Burns MD (1996) The influence of changes in food abundance on diving and surface-feeding seabirds. In: Studies of high latitude seabirds. IV. Trophic relationships and energetics of endotherms in cold ocean systems. Can Wild Serv Occas Pap 91:10-19

Moser HG, Smith PE (1993) Larval fish assemblages of the California current region and their horizontal and vertical distributions across a front. Bull Mar Sci 53:645-691

Mueter FJ, Peterman RM, Pyper BJ (2002) Opposite effects of ocean temperature on survival rates of 120 stocks of Pacific salmon (Oncorhynchus spp.) in northern and southern areas. Can J Fish Aquat Sci 59:456-463

Norton EC, MacFarlane RB, Mohr MS (2001) Lipid class dynamics during development in early life stages of shortbelly rockfish and their application to condition assessment. J Fish Biol 58(4):1010-1024

Peterson WT, Schwing FB (2003) A new climate regime in northeast pacific ecosystems. Geophys Res Lett 30:1896

Pinaud D, Weimerskirch H (2002) Ultimate and proximate factors affecting the breeding performance of a marine top-predator. Oikos 99:141-150

Ralston S, Howard DF (1995) On the development of yearclass strength and cohort variability in two northern California rockfishes. Fish Bull 93:710-720

Robinson CJ (2004) Responses of the northern anchovy to the dynamics of the pelagic environment: identification of fish behaviours that may leave the population under risk of overexploitation. J Fish Biol 64:1072-1087

Schwing FB, O'Farrell M, Steger JM, Baltz K (1996) Coastal upwelling indices, West Coast of North America 1946-95. US Dept. Commerce NOAA Tech Mem NMFS-SWFSC-231

Smith PE, Moser GH (2003) Long-term trends and variability in the larvae of Pacific sardine and associated fish species of the California Current region. Deep-Sea Res II 50: $2519-2536$

Steger JM, Schwing FB, Collins CA, Rosenfeld LK, Garfield N, Gezgin E (2000) The circulation and water masses in the Gulf of the Farallones. Deep-Sea Res II 47:907-946

Suryan RM, Irons DB, Kaufman M, Benson J, Jodice PGR, Roby DD, Brown ED (2002) Short-term fluctuations in forage fish availability and the effect on prey selection and brood-rearing in the black-legged kittiwake Rissa tridactyla. Mar Ecol Prog Ser 236:273-287

Takahashi A, Kuroki M, Niizuma Y, Kato A, Saitoh S, Watanuki Y (2001) Importance of the Japanese anchovy (Engraulis japonicus) to breeding rhinoceros auklets (Cerorhinca monocerata) on Teuri Island, Sea of Japan. Mar Biol 139:361-371

Van Pelt TI, Piatt JF, Lance BK, Roby DD (1997) Proximate composition and energy density of some North Pacific forage fishes. Comp Biochem Physiol A 118:1393-1398

Vermeer K, Devito K (1986) Size, caloric content, and association of prey fishes in meals of nestling rhinoceros auklets. Murrelet 67:1-9

Wroblewski JS, Richman JG, Mellor GL (1989) Optimal wind conditions for the survival of larval northern anchovy, Engraulis mordax: a modeling investigation. Fish Bull 87:387-395

Yen PPW, Bograd S, Sydeman WJ, Hyrenbach KD (2005) Springtime distributions of migratory marine birds in the California Current: Oceanic eddy associations and coastal habitat hotspots over 17 years. Deep-Sea Res II 52: 799-822

Yoklavich MM, Loeb VJ, Nishimoto M, Daly B (1996) Nearshore assemblages of larval rockfishes and their physical environment off central California during an extended El Nino event, 1991-1993. Fish Bull 94:766-782 